\title{
Pro-Social Behavior Analysis through Online Social Marketing with Three-Dimensional Credibility Model
}

\author{
Gliseria Jeannika Siauta \\ School of Economics and Business, Telkom University \\ Bandung, Indonesia \\ jeannikasiauta@gmail.com
}

\author{
Indrawati \\ School of Economics and Business, Telkom University \\ Bandung, Indonesia \\ indrawati@telkomuniversity.ac.id
}

\begin{abstract}
Marketers' current main concern is building stakeholder's pro-social behavior. This phenomenon has created 2015 year as the "year of pro-social brand." The Body Shop (TBS) is a company which really concerns with pro-social behavior program. The TBS Foundation (TBSF) was established, to inform and invite the public to change the world together. TBSF has cooperated with local campaigns in Indonesia, and created a need for the organization to create a credible website that can be accessed globally. TBSF needs to know what factors that affect these objectives. To find the factors, this study reviewed several papers published in international journals and found a model of Cugelman in 2010 that was considered to be fit with the objective of this study. To test if the Cugelman model can be used in this study, a modified questionnaire based on Cugelman was tested to 30 respondents. The result revealed that the modified questionnaire with 26 items was valid and reliable and ready to be used for further study.
\end{abstract}

Keywords - Pro-social Behavior; Online Social Marketing; 3DHCM(key words)

\section{INTRODUCTION}

Consumers are currently becoming more aware of green, environmentally safer products. They are also becoming more concerned about social issues such as environmental health, politics, human rights, etc. The Tomorrow People state that there are many critics, from consumers to companies. Based on an article on theguardian.com, 2015 will be the year of prosocial brands [1]. Marketing trends of this year are not only focused on sales but also on how companies create their marketing activities to increase their stakeholder's pro-social behavior.

One of the green products that consumers want is personal care. The global demand for organic personal care products were over $\$ 7.6$ billion in 2012 and are expected to reach $\$ 13.2$ billion by 2018 [2]. Based on an interview with Maya Ariyati (Marketing Lecture of Telkom University Bandung), The Body Shop (TBS) is a pioneer in organics personal care products. PR and Values Manager TBS Indonesia stated that in the current economy, teens are also using cosmetics and perfumes. This made the age range of TBS' loyal consumers wider from 25-35 years old to 15-35 years old women [3]. This has come to fruition because parents believe that TBS now has a safe formula for their cosmetics. Unfortunately though, men are more careless about organic products than women [4]. This causes TBS to look more closely at women as target consumers rather than their male counterparts.

To their prior commitment, TBS established The Body Shop Foundation (TBSF). In Indonesia, TBSF has cooperated with the Orangutan Foundation to protect orangutans as endangered animals. Along with TBS, Indonesian teens also like the Etude House, a competitor marketing business, from Korea. Etude also launched their organic personal care and cosmetic products in Indonesia, but they don't have an organization like TBSF. This gives them an advantage over Etude. We can find their work by visiting the organization's website, www.thebodyshopfoundation.org. Through this website, TBSF invites everyone around the world to join them to change society. Everyone can participate with them by joining their team, and also by buying their products.

It is necessary to analyze the factors that affect pro-social behavior of customers toward the websites. In 1990, Ohanian proposed and tested a three-dimensional human credibility model (3-DHCM) for celebrity endorsers in the US. Then, Cugelman adapted this model for his research about social marketing through 72 social campaign websites worldwide in four languages (English, Spanish, Portuguese, and French). Until now, writers have not yet found a website credibility model that fits Indonesian consumers.

\section{LITERATURE REVIEW}

\section{A. Three-Dimensional Human Credibility Model (3-DHCM)}

In order to achieve the objective as described in the introduction, literature reviews of theories and models related to social marketing are actually needed. Cugelman did research about online social marketing along with a few theories and models: Social Exchange Theory (SCT), Relationship Marketing (RM), Social Cognitive Theory (SCT), Elaboration Likelihood Model and Source Credibility (ELMSC), Media Equation and Functional Triad (MEFT). By studying those models and theories, Cugelman added Active Trust to 3-DHCM and Two-Dimensional Computer Credibility Model (2-DCCM) [5]. Three-Dimensional Human Credibility Model (3-DHCM) was first developed by Ohanian in 1990. In 2010, 3-DHCM was used by Brian Cugelman by modifying additional variables. 
The first model of 3-DHCM has three sub-variables (Trustworthiness, Expertise, and Attractiveness). Stefansson stated that today's popular model of source is credibility dominated by expertise, trustworthiness, and attractiveness [6]. Cugelman modified attractiveness to focus on visual appeal [5]. He added Active Trust as a variable between Website Credibility and Behavioral Intention.

\section{B. Website Credibility}

Ohanian defined Source Credibility as a term commonly used to imply a communicator's positive characteristics that affect the receiver's acceptance of a message [7]. Cugelman represented website credibility as a psychological judgement that a website's content is believable [5]. Empirically, during the development of a scale to measure source credibility, a significant association was shown between credibility and behavior intentions [5][7].

\section{Expertise}

According to Ohanian, expertise is referred to as "authoritativeness", "competence", "expertness", or "qualification" [7]. This study defines that the organization's website has the qualifications and competency to serve information about their social campaign.

\section{Visual Appeal}

Visual appeal is defined as a website's superficial aesthetic attractiveness [5]. Based on Cugelman, visual appeal had the strongest significant effect to active trust [5].

\section{E. Trustworthiness}

Trustworthiness is defined as the listener's degree of confidence in, and level of acceptance of, the speaker and the message [6]. This study defines the degree of confidence that readers have in the organization's website.

\section{F. Active Trust}

Bart, Shankar, Fareena, and Urban agreed that online trust has been considered a psychological intermediary between a website's physical characteristics and users' behavioral intention [5]. Cugelman said that active trust is a consumer's confidence in acting on the advice of a website[5]. This study uses this definition to define active trust.

\section{G. Pro-social Behavior}

Cugelman used behavioral impact as a dependent variable. He defined it as a change in users' campaign activity and future willingness to support the campaign, directly correlated to using the website. This study adapted this concept as prosocial behavior. Pro-social behavior, or voluntary behavior intended to benefit another, consists of actions which benefit other people or society as a whole, such as helping, sharing, donating, cooperating, and volunteering [8]. This study used Afolabi's definition to define pro-social behavior.

\section{H. Age and Gender}

Peterson and Vaught found that age was a significant predictor of ethical behavior [9]. They also reported a correlating interaction between age and gender. Their findings suggest that ethical attitudes develop at different rates for each gender, with the differences diminishing as age increases.

\section{Modified Three-Dimensional Human Credibility Model (3- DHCM)}

Based on the literature review above, this study proposed a modified 3-DHCM model as seen in figure 1.

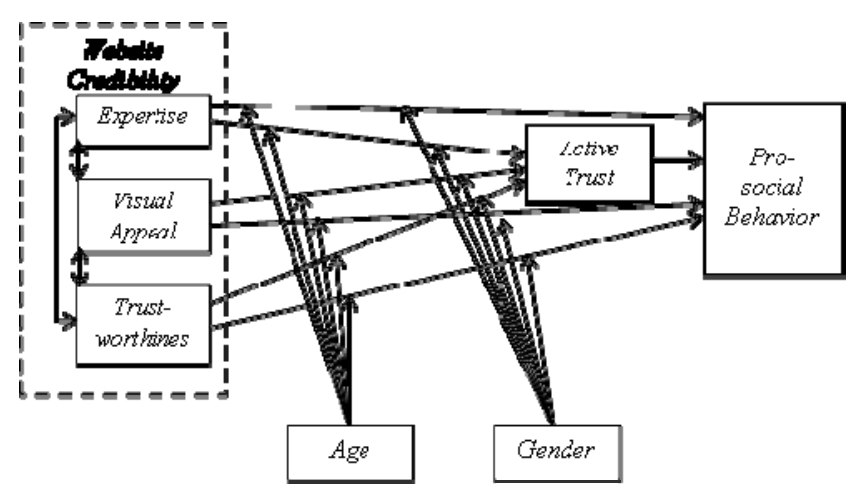

Fig. 1. Three-Dimensional Human Credibility Model

\section{RESUlts AND DisCUSSION}

To propose the pro-social behavior model for Indonesian consumers, writers interviewed B.J. Fogg, one of 2-DCCM's founders, to confirm the modified model in this study. Fogg said that he knows the Cugelman model, and argued that the age and gender are new improvements to the credibility model. After that, writers arranged the indicators for every variable to be a questionnaire. The questionnaire consists of 29 items in Bahasa (Indonesian language). It was shared to 30 respondents with significant at 0.05 and $\mathrm{r}$ table was 0,361 . The test used SPSS 16.0 for Windows. Only 26 items were valid and reliable.

TABLE I. The RESUlts OF VALIDITY AND RELIABILITY TEST

\begin{tabular}{|c|c|c|c|}
\hline Variables & Sub-variables & Indicator & $\begin{array}{c}\text { No. } \\
\text { of } \\
\text { Item }\end{array}$ \\
\hline \multirow{6}{*}{$\begin{array}{l}\text { Website } \\
\text { Credibility } \\
\text { (psychologic } \\
\text { al judgement } \\
\text { that TBSF } \\
\text { website's } \\
\text { content is } \\
\text { believable) }\end{array}$} & \multirow{5}{*}{$\begin{array}{l}\text { Expertise } \\
\text { (thebodyshop- } \\
\text { foundation.org } \\
\text { has } \\
\text { qualification } \\
\text { and } \\
\text { competency to } \\
\text { serve } \\
\text { information } \\
\text { about social } \\
\text { campaign of } \\
\text { The Body } \\
\text { Shop.) }\end{array}$} & $\begin{array}{l}\text { Content on TBSF website } \\
\text { reflects authors who are skilled } \\
{[5][10] \text {. }}\end{array}$ & 1 \\
\hline & & $\begin{array}{l}\text { Content on TBSF website } \\
\text { reflects authors who are } \\
\text { knowledgeable [5][10]. }\end{array}$ & 2 \\
\hline & & $\begin{array}{l}\text { TBSF website is produced by } \\
\text { qualified organization [10]. }\end{array}$ & 3 \\
\hline & & $\begin{array}{l}\text { TBSF website is produced by } \\
\text { experienced organization [10]. }\end{array}$ & 4 \\
\hline & & $\begin{array}{l}\text { TBSF website is produced by } \\
\text { reputable organization [5]. }\end{array}$ & 5 \\
\hline & Visual Appeal & website's & 6 \\
\hline
\end{tabular}




\begin{tabular}{|c|c|c|c|}
\hline Variables & Sub-variables & Indicator & $\begin{array}{c}\text { No. } \\
\text { of } \\
\text { Item }\end{array}$ \\
\hline & \multirow{5}{*}{$\begin{array}{l}\text { (TBSF } \\
\text { website's } \\
\text { superficial } \\
\text { aesthetic } \\
\text { attractiveness) }\end{array}$} & appearance is interesting [5]. & \\
\hline & & $\begin{array}{l}\text { Information on TBSF website } \\
\text { is complete [11]. }\end{array}$ & 7 \\
\hline & & $\begin{array}{l}\text { The content in TBSF website } \\
\text { is easy to access [5]. }\end{array}$ & 8 \\
\hline & & $\begin{array}{l}\text { The content in TBSF website } \\
\text { is easy to understand [5] [11]. }\end{array}$ & 9 \\
\hline & & $\begin{array}{l}\text { TBSF concerns about social } \\
\text { issue, such as environmental, } \\
\text { animal protection, and human } \\
\text { rights [5]. }\end{array}$ & 10 \\
\hline & \multirow{4}{*}{$\begin{array}{l}\text { Trustworthi- } \\
\text { ness } \\
\text { (the degree of } \\
\text { trustworthy } \\
\text { about } \\
\text { information in } \\
\text { the website } \\
\text { thebodyshop- } \\
\text { foundation.org } \\
\text { ) }\end{array}$} & $\begin{array}{l}\text { Information on TBSF website } \\
\text { is believable [12]. }\end{array}$ & 11 \\
\hline & & $\begin{array}{l}\text { I access TBSF website without } \\
\text { error [12]. }\end{array}$ & 12 \\
\hline & & $\begin{array}{l}\text { Information on TBSF website } \\
\text { is consistent [5]. }\end{array}$ & 13 \\
\hline & & $\begin{array}{l}\text { TBSF website's reputation is } \\
\text { good }\end{array}$ & 14 \\
\hline \multirow{6}{*}{$\begin{array}{l}\text { Active Trust } \\
\text { (subject's } \\
\text { confidence in } \\
\text { acting on the } \\
\text { advice of } \\
\text { TBSF } \\
\text { website) }\end{array}$} & & I am trustful [5]. & 15 \\
\hline & & $\begin{array}{l}\text { For me, organization } \\
\text { credibility who makes TBSF } \\
\text { website is important [5] [13]. }\end{array}$ & 16 \\
\hline & & $\begin{array}{l}\text { For me, website design affects } \\
\text { my opinion about TBSF [13]. }\end{array}$ & 17 \\
\hline & & $\begin{array}{l}\text { For me, the website gives an } \\
\text { overview about TBSF social } \\
\text { campaign [12]. }\end{array}$ & 18 \\
\hline & & $\begin{array}{l}\text { I am interested in the content } \\
\text { of TBSF website [12]. }\end{array}$ & 19 \\
\hline & & $\begin{array}{l}\text { At the time, I trust TBSF } \\
\text { website [12]. }\end{array}$ & 20 \\
\hline \multirow{6}{*}{$\begin{array}{l}\text { Pro-social } \\
\text { Behavior } \\
\text { (Perform } \\
\text { action which } \\
\text { benefit other } \\
\text { people or } \\
\text { society as a } \\
\text { whole after } \\
\text { visit TBSF } \\
\text { website) }\end{array}$} & & $\begin{array}{l}\text { I would spread information } \\
\text { based on issues from TBSF } \\
\text { website [5]. }\end{array}$ & 21 \\
\hline & & $\begin{array}{l}\text { I would tell others to use } \\
\text { environmentally } \\
\text { products [12]. }\end{array}$ & 22 \\
\hline & & $\begin{array}{l}\text { I would dispose trash } \\
\text { according to the category [5]. }\end{array}$ & 23 \\
\hline & & $\begin{array}{l}\text { I would buy no animal testing } \\
\text { products [5]. }\end{array}$ & 24 \\
\hline & & $\begin{array}{l}\text { I would buy TBS products } \\
\text { because of their role in social } \\
\text { and environmental issues. }\end{array}$ & 25 \\
\hline & & $\begin{array}{l}\text { If I have an empty TBS } \\
\text { package, I would return it to } \\
\text { TBS counters. }\end{array}$ & 26 \\
\hline
\end{tabular}

Based on table 1 above, 26 items were reliable and valid. Validation range was $0,381-0,795(>0,361)$. Reliability range was $0,941-0,946$. From 30 respondents, only two stated that the questionnaire was difficult, but didn't mention the items.

\section{CONCLUSION}

Based on the literature review and pilot test, the measurement items about pro-social behavior through website is as shown in Table 1. The measurement items were constructed by 26 statements from three independents subvariables and two dependent variables. The next process for the researchers is to continue to share the questionnaire, to predict further pro-social behavior through websites in Indonesia.

\section{References}

[1] J Sachs. "2015 will be the year brands take a public stand on social issues". [Article].2015. Retrieved January 6, 2015, from The Guardian site, http://www.theguardian.com.

[2] A Penning. "Demand for Organic Beauty to Grow to Over $\$ 13$ Billion by 2018", Report Says. 2013, Retrieved September 22, 2015 from Cosmetics \& Toiletries site, http://www.cosmeticsandtoiletries.com.

[3] L Intana. (2013, October 23). Tren Konsumen The Body Shop di Indonesia Bergeser. Retrieved September 22, 2015 from Majalah SWA site, http://swa.co.id.

[4] G Polakovic. "Are Women Greener than Men?". 2012. Retrieved September 22, 2015 from Los Angeles Times site, http://articles.latimes.com.

[5] B Cugelman. "Online Social marketing: Website Factors in Behavioural Change". Published PhD thesis, University of Wolverhampton. 2010. Retrieved February 4, 2015, from http://wlv.openrepository.com.

[6] J. K. Stefansson, "The Effects of Perceived Dominance in Persuasion". Published master's thesis. 2010, Retrieved August 20, 2015, from http://www.ub.uit.no8080.

[7] R Ohanian. "Construction and Validation of a Scale to Measure Celebrity Endorsers' Perceived Expertise, Trustworthiness". Journal of Advertising, 19(3), 1990, pp. 39-52. Retrieved March 10, 2015, from http://xa.yimg.com.

[8] O A Afolabi. "Psychosocial Predictors of Prosocial Behaviour among A Sample of Nigerian Undergraduates". European Scientific Journal, 10(2), 2014, pp.241-266. Retrieved February 25, 2015 from http://eujournal.org.

[9] D R Peterson \& B C Vaught. "Ethical Beliefs of Business Professionals: A Study of Gender, Age and External Factors". Journal of Business Ethics (31), 2001, pp.225-232.

[10] J E Forbes. "Measuring Consumer Perceptions of Credibility, Engagement, Interactivity and Brand Metrics of Social Network Sites". Published master's thesis, Lousiana State University. 2010, Retrieved August 12, 2015, from http://etd.lsu.edu.

[11] L Khosaim. "The Impact of Web Design Dimensions on Consumer Trust at Different Price Ranges". Published master's thesis. 2013. Retrieved August 11, 2015, from http://dalspace.library.dal.ca.

[12] H Kharouf. "Relationship marketing: an evaluation of trustworthiness within the Jordanian hotel sector". Unpublished PhD Thesis, Coventry University. 2010. Retrieved August 11, 2015, from http://curve.coventry.ac.uk.

[13] S T Bulu. "Communication Behaviors and Trust in Collaborative Online Teams" Published master's thesis, The Department of Computer Education and Instructional Technologies. 2003, Retrieved August 11, 2015, from http://etd.metu.tr 